\title{
Comparison of the pain pressure threshold on the pelvic floor in women with and without primary dysmenorrhea
}

\author{
Comparação do limiar pressórico de dor no assoalho pélvico em mulheres com e sem \\ dismenorreia primária
}

Victória dos Santos Guarda Lima ${ }^{1}$, Guilherme Tavares de Arruda ${ }^{1}$, Cyntia Scher Strelow ${ }^{1}$, Michele Adriane Froelich ${ }^{1}$, Michele Forgiarini Saccol ${ }^{1}$, Melissa Medeiros Braz ${ }^{1}$

DOI 10.5935/2595-0118.20190019

\section{ABSTRACT}

BACKGROUND AND OBJECTIVES: Primary dysmenorrhea is characterized as menstruation with painful conditions in women with no associated pathologies, whose pain sites are classically investigated in the abdomen. However, it is known that the pelvic floor can also be compromised by primary dysmenorrhea and can be a source of hyperactivity of this musculature. The objective of this study was to compare the pain pressure threshold in the pelvic floor of women with and without primary dysmenorrhea.

METHODS: An observational, quantitative and cross-sectional study was conducted with young women. The sample consisted of 20 women divided into two groups: with primary dysmenorrhea $(n=10)$ and without primary dysmenorrhea $(n=10)$. The Adapted Assessment Questionnaire was applied for the data collection on the characteristics of the menstrual cycle followed by an evaluation of the pressure threshold of the pelvic floor of the participants using the Microfet 2 HHD manual dynamometer. RESULTS: There was no significant difference in pressure pain threshold between the groups on the left side $(\mathrm{p}=0.156)$ and right side $(\mathrm{p}=0.198)$ of the pelvic floor.

CONCLUSION: In this women sample, the occurrence or non-occurrence of primary dysmenorrhea was not associated with an increase in the pain pressure threshold of the pelvic floor. Keywords: Dysmenorrhea, Pelvic floor, Women.

\footnotetext{
Victória dos Santos Guarda Lima - Dhttps://orcid.org/0000-0002-7268-6078; Guilherme Tavares de Arruda - Dhttps://orcid.org/0000-0001-5994-3247; Cyntia Scher Strelow - Dhttps://orcid.org/0000-0003-1585-4458;

Michele Adriane Froelich - Dhttps://orcid.org/0000-0001-8747-7650;

Michele Forgiarini Saccol - Dhttps://orcid.org/0000-0002-7894-690X

Melissa Medeiros Braz - Dhttps://orcid.org/0000-0002-9138-0656.

1. Universidade Federal de Santa Maria, Departamento de Fisioterapia e Reabilitação, Santa Maria, RS, Brasil.

Submitted on November 11, 2018.

Accepted for publication on February 19, 2019.

Conflict of interests: none - Sponsoring sources: none.

Correspondence to:

Av. Roraima no 1000, Cidade Universitária - Bairro Camobi

97105-970 Santa Maria, RS, Brasil.

E-mail: gui_tavares007@hotmail.com

( ) Sociedade Brasileira para o Estudo da Dor
}

\section{RESUMO}

JUSTIFICATIVA E OBJETIVOS: A dismenorreia primária é caracterizada como uma menstruação com quadros álgicos em mulheres sem doenças associadas, cujos pontos de dor são investigados classicamente no abdômen. Entretanto, sabe-se que o assoalho pélvico também pode ser comprometido pela dismenorreia primária e pode ser fonte de hiperatividade dessa musculatura. O objetivo deste estudo foi comparar o limiar pressórico de dor no assoalho pélvico de mulheres com e sem dismenorreia primária.

MÉTODOS: Foi realizado um estudo observacional, com abordagem quantitativa e de caráter transversal com mulheres jovens. A amostra constituiu de 20 mulheres divididas em dois grupos: com dismenorreia primária $(\mathrm{n}=10)$ e sem dismenorreia primária $(\mathrm{n}=10)$. O Questionário Adaptado de Avaliaçáo foi aplicado para a coleta dos dados sobre as características do ciclo menstrual, seguido de uma avaliação do limiar pressórico do assoalho pélvico das participantes com o dinamômetro manual Microfet 2 HHD. RESULTADOS: Não houve diferença significativa no limiar de dor à pressão entre os grupos no lado esquerdo $(\mathrm{p}=0,156)$ e lado direito $(\mathrm{p}=0,198)$ do assoalho pélvico.

CONCLUSÁO: Nesta amostra de mulheres, a ocorrência ou não de dismenorreia primária não foi associada ao aumento do limiar pressórico de dor do assoalho pélvico.

Descritores: Diafragma pélvico, Dismenorreia, Mulheres.

\section{INTRODUCTION}

Primary dysmenorrhea (PD) is characterized by menstruation with painful periods in women with no lesions in the pelvic organs. It is also considered as a gynecological dysfunction that manifests with pain in the lower abdomen, which may radiate to the paravertebral region and thighs. It usually begins in adolescence and is accompanied by nausea, vomiting, and diarrhea, varying in intensity according to the commitment in daily activities ${ }^{1,2}$.

The most accepted theories to explain the pain in women with $\mathrm{PD}$ are the production and excess release of prostaglandins during menstruation through the endometrium, which would cause uterine hypercontractility, hypoxia, and ischemia ${ }^{3,4}$.

More frequently, the abdominal region is investigated in women with PD. However, current research considers the hypothesis that, during the menstrual cycle, the hormonal variations of these women may be related to the pain sensitization mecha- 
nisms of the central nervous system (CNS), making the pelvic floor $(\mathrm{PF})$ more sensitized during the entire menstrual cycle ${ }^{5,6}$. A recent study ${ }^{6}$ demonstrated hyperalgesia during the menstrual cycle of women with PD, especially in the deep tissues, as evidence of the presence of central sensitization. The pain thresholds for pressure, heat and electricity are reduced in the abdominal, paravertebral and limb regions in the menstrual phase in patients with $\mathrm{PD}^{6}$. However, research is still incipient in relation to painful PF sites in women with PD.

Central sensitization may be associated with pain in the PF of women with PD, by the passage of nociceptive stimuli through the facilitation of the CNS, which generates tension and hyperactivity in the pelvic floor muscles (PFM). These pelvic structures, when affected, can result in cognitive, sexual, behavioral and emotional dysfunctions. In addition, this impairment may be associated with urinary incontinence ${ }^{7}$ in the future.

It is of fundamental importance to have a better knowledge of the painful places to be able to intervene on them. Physiotherapy has resources for pain relief and many other ways of minimizing the effects of pain in PF have been studied.

The objective of this study was to compare the pain pressure threshold in the pelvic floor of women with and without PD.

\section{METHODS}

An observational cross-sectional study with a quantitative approach was carried out with university students from a Higher Education Institution of the south of Brazil, from March to June 2018.

The sample consisted of young women divided into two groups: with PD (G1) and without PD (G2). The study included women between the ages of 18 and 35, with and without complaints of PD, nulligans and users of oral contraceptives (OC) in a non-continuous way. Women with a diagnosis of secondary dysmenorrhea or who presented, at the time of data collection, some diagnosed gynecological pathology were excluded.

The sample calculation was performed using G-Power software 3.1.9.2, based on the results of a pilot study with 10 women divided into two groups. It was estimated a sample of 8 individuals in each group to achieve a level of significance (alpha) of $5 \%$ $(\mathrm{p}<0.05)$ and power (beta) of $80 \%$.

The data collection occurred during the menstrual cycle at a painless time between the second and third week of OC use. The instruments used to collect the data were the Adapted Questionnaire according to the criteria of Lefebvre et al. ${ }^{8}$, which includes information such as personal characteristics, gynecological history and characteristics of PD; and an algometer, Microfet 2 HHD (Hoggan Health, United States) manual dynamometer, for evaluation of the pressure threshold of pain, the point where the pain starts. All measurements of the dynamometer were expressed in $\mathrm{kg} / \mathrm{cm} 3$. The protocol for evaluation of pain points was based on the Molins-Cubero et al. ${ }^{\text {. F For }}$ the PFM evaluation (levator ani and coccygeal), the patient was asked to stay in the lithotomy position, with the support of the lower members and relaxed PFM, locating the points located bilaterally in the pelvis (Figure 1).

The participant was shown how algometry would be performed on the adductor muscle of the thumb, after which she was asked to speak the word "pain" when she felt a painful stimulus in the PF for three repetitions. For the PF evaluation, the algometer was positioned perpendicularly at each of the demarcated points, increasing the pressure at a constant rate $(1 \mathrm{~kg} / \mathrm{s})$, without abrupt variations. Measurements were made three times consecutively at each point, on the right side, and the left side, with a 30-second interval between each repetition, considering the average between these measurements. Participants were examined by a single researcher to maintain data collection consistency.

The research began after approval of the Institutional Research Ethics Committee under Opinion number 2.384.714 in 2017.

\section{Statistical analyses}

All variables were analyzed for normality using the Kolmogorov-Smirnov test so that the variables that presented Gaussian distribution were submitted to parametric tests, and those that did not were analyzed through non-parametric tests. Parametric data were presented in mean $\pm S D$ and non-parametric variables in median and interquartile range. Statistical differences between

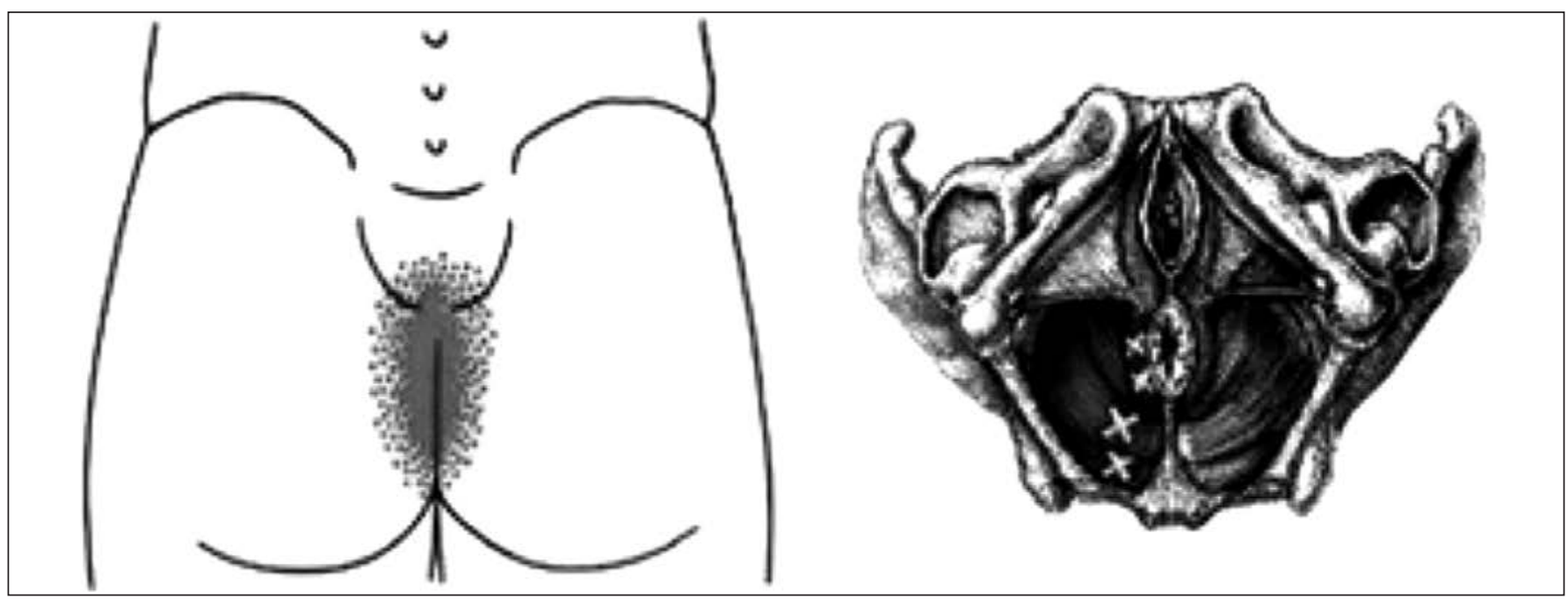

Figure 1. Representation of the two assessed points in algometry ${ }^{9,10}$. 
groups were analyzed using Student's t-test or the Mann-Whitney test. Values of $\mathrm{p}<0.05$ were considered statistically significant, using a 95\% confidence interval. All statistical analysis was performed using GraphPad Prism software, version 6.0 for Windows (GraphPad Software, San Diego, CA).

\section{RESULTS}

Twenty-four young women were evaluated. Under the eligibility criteria, the sample consisted of 20 women divided into two groups: G1 $(n=10)$ and G2 $(n=10)$. The flowchart with the inclusion and exclusion criteria is shown in figure 2.

Table 1 presents data on the groups' characterization of body mass index (BMI), age at menarche, bleeding time and blood flow.

Table 1. Characterization of young women

\begin{tabular}{lccc}
\hline & $\mathrm{G} 1$ & $\mathrm{G} 2$ & $\mathrm{p}$-value \\
\hline Age (years) & $21.0 \pm 0.3$ & $22.5 \pm 0.4$ & $0.015^{\star}$ \\
Body mass index $\left(\mathrm{kg} / \mathrm{m}^{2}\right)$ & $23.1 \pm 0.9$ & $22.1 \pm 0.8$ & 0.449 \\
Menarca (years) & $12.7 \pm 0.5$ & $12.8 \pm 0.4$ & 0.878 \\
Bleeding time (days) & $3.0(2.0-3.0)$ & $2.5(2.0-3.0)$ & 0.449 \\
Menstrual flow (grade) & $2(2.0-3.0)$ & $2(1.75-2.0)$ & 0.232 \\
Light & $1(10 \%)$ & $2(20 \%)$ & \\
Moderate & $6(60 \%)$ & $8(80 \%)$ & \\
Intense & $2(30 \%)$ & 0 & \\
Family history of PD & $7(70 \%)$ & 0 &
\end{tabular}

$\overline{\mathrm{G} 1}$ = with primary dysmenorrhea; $\mathrm{G} 2$ = without primary dysmenorrhea; $\mathrm{PD}=$ primary dysmenorrhea. Data expressed as mean $\pm S D$, median, interquartile range and percentage. ${ }^{*} p<0.05$

Table 2 presents the results of the pain pressure threshold in the groups during the period outside the menstrual bleeding. There was no statistically significant difference between groups.

Table 2. Pressure pain threshold of young women

\begin{tabular}{lccc}
\hline Pressure threshold & G1 & G2 & p-value \\
\hline Right side & $2.4 \pm 0.2$ & $2.8 \pm 0.2$ & 0.156 \\
Left side & $2.5 \pm 0.2$ & $2.9 \pm 0.3$ & 0.198
\end{tabular}

G1 = with primary dysmenorrhea; G2 = without primary dysmenorrhea; Data expressed as mean \pm SD. ${ }^{*} p<0.05$.

\section{DISCUSSION}

In this study, we sought to compare the pain pressure threshold in the PF of women with and without PD. The participants of the G1 were younger than those of G2, and no difference was observed between the PF pain pressure threshold between the groups. Thus, despite the occurrence of pain during the menstrual period, the PF of the G1 did not present pain sensitization at the central level, and it is possible to influence the use of OC in response to noxious stimuli.

Vincent et al. ${ }^{11}$, when comparing pain tolerance among women with and without PD who were not users of OC, found that the former showed higher responses to noxious stimulation, not only at the moment of pain but throughout the cycle. This suggests that women have central sensitization to pain related to the chronicity of pain. In the present study, the time of complaint of PD was not investigated and, considering that the patients did not present chronic pain, this may have contributed to the non-occurrence of central sensitization, in addition to the results that were similar between the two groups.

The evaluation of the pressure pain threshold in the lower limb muscles and trunk of young women with PD and non-users of OC has already been demonstrated. Alfieri et al. ${ }^{12}$ observed a reduction in the pain tolerance values at the follicular phase of the menstrual cycle, suggesting that pain tolerance is negatively influenced by the follicular phase of the cycle. Although the mechanisms remain unclear, female hormones interact with the nociceptive processes at multiple CNS and peripheral levels, and hormonal variations are associated with variations in the pain experience. However, in another study, no difference in pain sensitivity was observed during the menstrual cycle phases, suggesting that there was no consensus in the studies regarding pressure tolerance to pressure in PD patients 5 .

For women who do not use OC, there is a fluctuation in pressure tolerance, which is lower in the menstrual phase. However, for women using OC, the threshold seems to remain the same at different stages of the cycle ${ }^{13}$. It has already been shown that women who used OC presented a lower variation in the

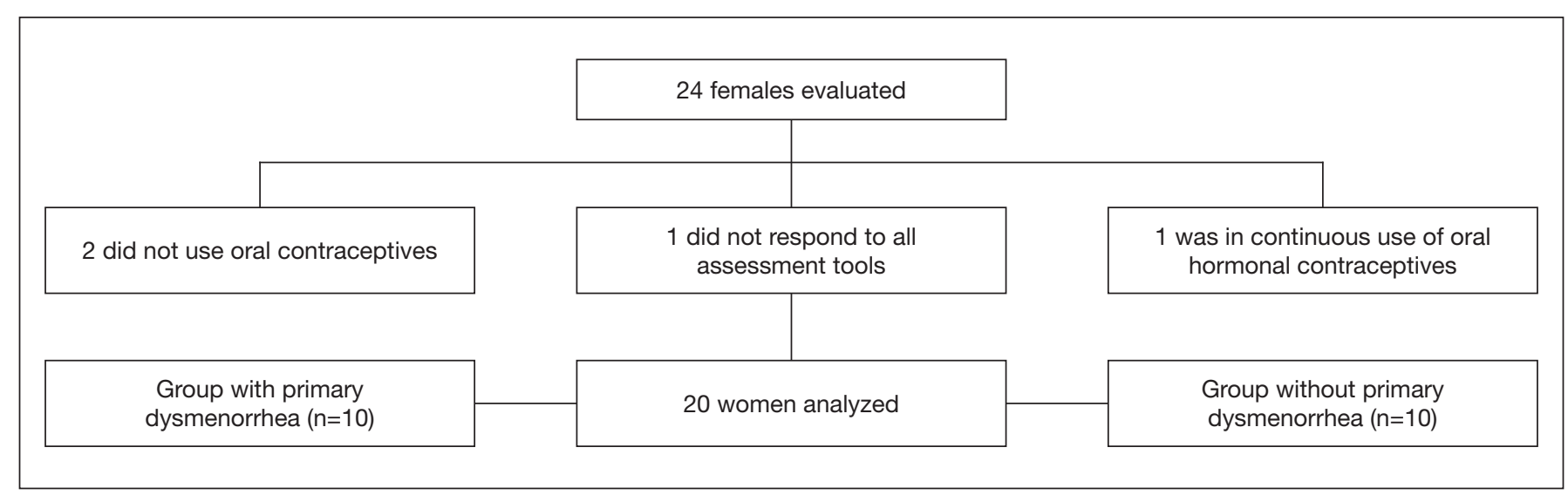

Figure 2. Flowchart of inclusion and exclusion criteria 
pressure pain threshold compared to those who did not use this medication ${ }^{14}$. Similarly, another study ${ }^{15}$ examined the influence of the menstrual cycle in women with symptoms of temporomandibular joint dysfunction and found that women who have used OC, with or without PD, showed higher tolerance to pain when subjected to algometry. Comparing OC and non-OC users, the difference in pain tolerance was observed throughout the cycle only in women who did not use OC, which could indicate that the hormonal variation along the cycle may influence the perception of pain. Women who use OC showed no significant variations in the perception of pain during the menstrual cycle, since hormonal variation is small, which lessens the effects of the same cycle, suggesting that the OC can modulate pain.

It should be emphasized that no studies were found that evaluated the PF pressure threshold in women with and without $\mathrm{PD}$. In the present study, in relation to the values found in the non-menstrual phase, it was observed that the PF pain threshold values were lower than those of the studies evaluating the abdomen and anteroposterior iliac spines ${ }^{16}$. In addition, no reference values were found for women in this age group for comparison. Sherman et al. ${ }^{17}$ observed a variation in pain intensity at different stages of the menstrual cycle, but not at the blood pressure threshold. However, another study ${ }^{18}$ concluded that both the PD and the phase of the cycle might influence the pain threshold. Thus, it is assumed that the differences between the studies may relate to the different tissues evaluated and the type of stimulus that was given, so that there was little difference in the effect of the menstrual cycle on the response to pain by specific stimuli, except for electrical stimulation ${ }^{15}$.

In the literature, PD charts are related to family history. Lopes ${ }^{13}$ analyzed 48 women with PD and found that $70 \%$ had a family history of menstrual cramps. Likewise, the present study, in which $70 \%$ of the women with $\mathrm{PD}$ reported having relatives with menstrual cramps, corroborates the findings of another study ${ }^{19}$, in which women who had mothers with PD had a better chance of developing PD.

This study was the first to evaluate the pressure pain threshold in the PF algometry. Moreover, it stands out for evaluating women users of OC that, as previously described, can influence the sensation of pain throughout the cycle.

\section{CONCLUSION}

Apparently, the presence of primary dysmenorrhea does not influence the pressure pain threshold in the pelvic floor of young women using oral contraceptives.

\section{REFERENCES}

1. Tozun M, Unsal A, Ayranci U, Arslan G. Prevalence of disordered eating and its impact on quality of life among a group of college students in a province of west Turkey. Salud Publica Mex. 2010;52(3):190-8.

2. Araujo LM, Bastos WT, Silva JMN, Ventura PL. Diminuição da dor em mulheres com dismenorreia primária, tratadas pelo método Pilates. Rev Dor. 2012;13(2):119-23.

3. Kannan P, Claydon LS. Some physiotherapy treatments may relieve menstrual pain in women with primary dysmenorrhea: a systematic review. J Physiother. 2014;60(1):13-21.

4. Yu YP, Ma LX, Ma YX, Ma YX, Liu YQ, Xie JP, et al. Immediate effect of acupuncture at Sanyinjiao (SP6) and Xuanzhong (GB39) on uterine arterial blood flow in primary dysmenorrhea. J Altern Complement Med. 2010;16(10):1073-8.

5. Iacovides S, Avidon I, Baker FC. What we know about primary dysmenorrhea today: a critical review. Hum Reprod Update. 2015;21(6):762-78.

6. Terzi R, Terzi H, Kale A. [Evaluating the relation of premenstrual syndrome and primary dysmenorrhea in women diagnosed with fibromyalgia]. Rev Bras Reumatol. 2015;55(4):334-9.

7. Hoffman D. Central and peripheral pain generators in women with chronic pelvic pain patient centered assessment and treatment. Curr Rheumatol Rev. 2015;11(2):146-66.

8. Lefebvre G, Pinsonneault O, Antao V, Black A, Burnett M, Feldman K, et al. Primary dysmenorrhea consensus guideline. J Obstet Gynaecol Can. 2005;27(12):1117-46. English, French.

9. Molins-Cubero S, Rodríguez-Blanco C, Oliva-Pascual-Vaca A, Heredia-Rizo AM, Boscá-Gandía JJ, Ricard F. Changes in pain perception after pelvis manipulation in women with primary dysmenorrhea: a randomized controlled trial. Pain Med. 2014;15(9):1455-63.

10. Travell JG, Simons DG. Dor e Disfunção Miofascial - Manual dos pontos-gatilho. 2. ed. Porto Alegre: Artmed Editora; 2006.

11. Vincent K, Warnaby C, Stagg CJ, Moore J, Kennedy S, Tracey I. Dysmenorrhoea is associated with central changes in otherwise healthy women. Pain. 2011;152(9):1966-75.

12. Alfieri FM, Bernardo KM, Pinto YS, Silva NC, Portes LA. Pain tolerance and cardiorespiratory fitness in women with dysmenorrhea. Rev Dor. 2017;18(4):311-5.

13. Lopes KN. Avaliaçáo dos limiares sensitivo e doloroso em mulheres com dismenorreia primária moderada ou grave [Dissertação]. Ribeirão Preto: Universidade de Sáo Paulo, Faculdade de Medicina de Ribeirão Preto; 2016.

14. Dao TT, Knight K, Ton-That V. Modulation of myofascial pain by the reproductive hormones: a preliminary report. J Prosthet Dent. 1998;79(6):663-70.

15. Lobato VL, Bauru O. Influência do ciclo menstrual nas alteraçôes de limiar de dor a pressão. Dissertaçấo de Mestrado FOB. 2007.

16. Stallbaum JH, Silva FS, Saccol MF, Braz MM. Controle postural de mulheres com dismenorreia primária em dois momentos do ciclo menstrual. Fisioter Pesqui. 2018;25(1):74-81.

17. Sherman JJ, LeResche L, Mancl LA, Huggins K, Sage JC, Dworkin SF. Cyclic effects on experimental pain response in women with temporomandibular disorders. J Orofac Pain. 2005;19(2):133-43.

18. Giamberardino MA, Berkley KJ, Iezzi S, de Bigontina P, Vecchiet L. Pain threshold variations in somatic wall tissues as a function of menstrual cycle, segmental site and tissue depth in non-dysmenorrheic women, dysmenorrheic women and men. Pain. 1997;71(2):187-97.

19. Yanez N, Bautista-Roa SJ, Ruiz-Sternberg JE, Ruiz-Sternberg AM. Prevalencia y factores asociados a dismenorrea en estudiantes de ciencias de la salud. Rev Cienc Salud. 2010;8(3):37-48. 